\title{
Correctional Programs in the State Prisonsof India: An Analysis with reference to Uttarakhand State
}

\author{
Shalini Bahuguna ${ }^{1}$, Dr. Ashish Kumar Singhal ${ }^{2}$ \\ ${ }^{1}$ Research Scholar, ICFAI Law School, The ICFAI University Dehradun \\ ${ }^{2}$ Associate Professor, ICFAI Law School, The ICFAI University Dehradun
}

\begin{abstract}
Human rights jurisprudence has greatly contributed to criminal reforms and has had an impact on India. Crime reforms across the globe also have an impact on India. The conceptualization with respect to penal reform originated in the reformist theory of punishment. ${ }^{1}$ The time prison must have such meaning that enhances the values of the reform in it. The reformer's appearance is about to add a sense of humanity in the system of criminal reformation and also to add the human values into the system of prison and prison officials have to work to achieve it. ${ }^{2}$ The level of protection guaranteed by the law for the reformatory therapy of prisoners must be carried out within a national legal framework and India does not have the same.
\end{abstract}

Key Words: Human Rights, Correctional Programme, Prisoners, Administration

\section{Introduction:}

The arrangement of jail organization in our nation is over 100 years of age. The development, while yet ending and utilized uniquely in a few and not be able to reflect in the prisons of India, nevertheless give guarantee of the arrangement of treating guilty parties. Now a days the brutal methods of treatment is not practiced, and such methods has been replaced by several new methods including outside of jail work, programs for advancement of the literacy, their societal aspects like, recreational and correctional plans, community work and reasonable wage scheme. Several instrumentations have been inseminated for treatment of prisoners with great amount of freedom and relatively better discipline. ${ }^{3}$

"Comprehensively, the presence of detainment facilities in our public is an old wonder since Vedic period where the counter social components were kept in a spot recognized by the rulers to ensure the public against wrongdoing. Prisons were considered as a House of Captives where prisoners were kept for retributory and deterrent punishment". 4

\section{Correctional Programmes: A Concept}

The institution of prison basically works on the two process theories one for the elimination of the criminals from society and second for the basic reformation and rehabilitation of the offenders under institutional treatment by blanketing out conditions which in the first place turned them into law-violators.

Correctional program refers to a type of program to which the criminal offenders are submitted. It includes both supervision and educational training given to correct the criminal offenders. Sometimes the correctional program is given as part of the sentence. It is mandatory for juvenile delinquents.

Object of correctional program is to reform a criminal by helping the offenders to overcome their past mistakes and learn useful skills. Correctional program includes high-school equivalency training, mental health diversion, writing seminars and substance abuse education. Torture in custody against Prisoners results in deprivation of the right to life, personal liberty, dignity, etc. in many cases, it results in unnatural deaths. Such a serious problem, which threatens fundamental human rights, has remained unexplored and no meaningful research has been conducted to examine the problem nationally and specifically in the State of Uttarakhand.

\section{Importance of Prisons and Role of Correctional Programme}

The primary object and function of criminal justice system is prevention of crime or at least reduction of crime rate. In each democratic society, jail has an interesting function as a proper organization of the criminal justice framework. The motivation behind detainment as a discipline is sufficiently plain - the individual who has submitted a wrong should endure consequently. Since a wrongdoing is a wrong devoted against the kingdom. Imprisonment ought to be punishment, no longer best via depriving the man or woman of his liberty, however via implementing a sort of alleged severe condition for the prisoners to live in.

As classified below the three main purpose of the prison system:

1. Custodial

2. Coercive and

3. Correctional.

Prison primarily considered as a place for the custodian of the prisoners, but the views has been changed with the passage of time and the custodial manner transform to the correctional manner primarily also the human rights perspective was seen to be considered. The major consideration for the prison system is rehabilitation, education, training, and work.

\footnotetext{
${ }^{1}$ Rupert Cross, Punishment Prison and The Public, Stevens and Sons, London, (1971) p. 43.

2 M.J. Sethna, Society and the Criminal, N.M. Tripathi Pvt. Ltd., Bombay, (3 ${ }^{\text {rd }}$ edi., 1971), p.352

VidyaBhushan, Prison Administration in India, S. Chand \& Co., (1970), p. 246

${ }^{4}$ http://www.bprd.nic.in/WriteReadData/userfiles/file/5261991522-Part\%20I.pdf
} 
In reference to the abovementioned it can be implied that a great amount of research has been conducted which points out the following shades:

1. The Literacy rate of the prisoners is significantly low across the globe.

2. The prisoners lack with the basic life skills.

3. The rehabilitation programs will be a great aspect to bridge the gap and gray shades

"The provision of constructive activities in prisons assists in rendering life in prison more like life outside. This is also referred to as the principle of normalization". 5

Physical, mental and psychological care and support system Substance abuse treatment Addressing behavior and attitudes Education and vocational training Work experience Types of prison-based rehabilitation programs as per rule 5(1) of the U.N. Standard Minimum Rules for Treatment of Prisoners. "Spending sufficient time engaged in meaningful educational or vocational training activities or productive work forms what the Nelson Mandela Rules call normal occupational life which prison administrations should seek to replicate as far as possible. Leading a busy life in prison can help reduce the risk of prisoners' developing depression, other mental health problems or limitations in prisoners' ability to lead a self-supporting and independent life (institutionalization or learned helplessness).",

The measures related to the educational matters, vocational courses, social activities within the prison premises and also the concerns of the protection, and security in prison centers, and help them change into (extra) fantastic environments. Prisoners engaged in constructive sports are less possibly to end up disaffected and reason troubles. Rehabilitation method prisoners are less difficult to control and less liable to violence. While protection and rehabilitation are from time to time visible as opposites, properly-run rehabilitation packages beautify safety and manipulate internal prisons. Work can create financial and special resources for each detainees took on such packages in addition to for the jail machine. These may be immediately assets, as an instance in prison facilities which domesticate their own food, or via the work which detainees might also strive in an effort to clean and maintain the jail; they could additionally be indirect sources.

The above justifications exemplify why prison framework ought to offer rehabilitation training, social considerations etc. They display that there are advantages which collect now not most effective for the prisoners involved, yet further for prison control and more vast society. Publicizing the benefits and advantages that jailprimarily focused on the aspects of the rehabilitation which brings in this manner may be a useful manner of generating and presenting political will to reform prisons, in addition to nurturing public assistance and knowhow. Some may additionally argue with rehabilitation as being too gentle on offenders, and others may additionally criticize paintings programs, as a shape of reasonably-priced Labor.

\section{Empirical Study with Reference to Prisons in the State of Uttarakhand}

The Digest of Justinian, in Roman law established the custodial principle with the statement that "a prison is for confinement, not for punishment and in countries that followed Raman law the principle that imprisonment was not a legal punishment was dominant for many years."

Similar approach has been adopted by the English courts and it was stated as "The prisons of the middle ages were, therefore, concurred only with holding prisoners awaiting trial. Penal institutions were chiefly dungeons or detention rooms in secure parts of castles or city towers, used to detain prisoners awaiting trial or execution of sentence. The punishments imposed were torture, banishment, exile, death, branding, mutilation, but never imprisonment." 8

The preliminary methodology of the prison system was exercised on the convicted offenders. The function is still prevalent in England, since those commits civil wrong or failed to pay their debts or for the contempt of court and thus may be secure release by paying what they owe or purging their contempt. ${ }^{9}$

"The purposes of prison are protection of the community, supply of food, clothing, shelters to convicted criminals, and protection of inmates from each other and from persons in the outside community, imposition of punishment and rehabilitation of criminals. The three principal sections in this division of labor are a hierarchy of custodial ranks, an industrial hierarchy, and a social welfare agency-and they are devoted to keeping inmates, using inmates, and serving inmates." 10

The patriarchal system of prison since last 3 decades has advanced the stature of social organizations which has revolted against the coercive actions by the prison authorities. It isn't any extra a resting floor inside the prison

\footnotetext{
${ }^{5}$ For a recent review, see Justice Analytical Services/Scottish Government (2015): What Works to Reduce Reoffending: A summary of the Evidence.

${ }^{6}$ With regard to work programs in prisons, also see Rule 99(1) of the Nelson Mandela Rules: "The organization and methods of work in prisons shall resemble as closely as possible those of similar work outside of prisons, so as to prepare prisoners for the conditions of normal occupational life."

${ }^{7}$ As per Roman Law as stated in Digest of Justinian

${ }^{8}$ AmarendraMohanty, Indian Prison System, Ashish Publishing House, New Delhi, (1990), p. 2-3 ${ }^{9}$ ibid

${ }^{10}$ Donald R. Cressy, “The Prison: Studies in Institutional and Organizational and Change”, Holt, Rinehart and Winston, Inc. New York, (1961), p.5
} 
process in which loss of life penalty, banishment, or lifestyles transportation can be the decision. ${ }^{11}$ The U.N. Standard Minimum Rules for the Treatment of Prisoners ${ }^{12}$ could be considered as the role model statute which sets an International standard in a true sense that "set out what is generally accepted as being good principles and practice in the treatment of prisoners and prison management". ${ }^{3}$

\section{Methodology: -}

In the present study the methodology applied to conduct this research is both Doctrinal and Non-Doctrinal. As this study majorly based on the primary data thus the researcher has usedNon-Doctrinal method to collect the sample through field work in the jails of Uttarakhand on the prisoners available at the time of research through a structured questionnaire consists of the optional, open ended, closed, multiple choice, rank order, questions available in Hindi and English language in which both qualitative and quantitative information was collected. The collected data was tested through the SPSS software through chi square test and R programming where applicable. This has highlighted the various facets of the reality which was observed by the researcher by first hand data which was collected throughout the prisons of Uttarakhand (as permitted by the competent authorities) and based on this the following Hypothesis was tested followed by the generaldetails.

\section{Hypothesis: -}

The corresponding hypotheses for the study are as follows:

- HP1. The traditional fulcrum of prison administration is too obsolete with the passage of time

- HP2. Mechanism for safeguarding rights of the inmates enshrined in Legal provisions in India are inadequate to deal with the rights of inmates

- HP3. Correctional programs implemented in Uttarakhand are not in consonance with Human Rights Jurisprudence.

Hypothesis 1. The traditional fulcrum of prison administration is too obsolete with the passage of time

\begin{tabular}{|l|l|l|}
\hline SN & Proposed Relationship & Results \\
\hline $\mathbf{1}$ & Age - Participation in the Cultural Programs which are conducted in the prison & Negative, Accepted \\
\hline $\mathbf{2}$ & Age - Violation of rights in the Prison & Positive, Rejected \\
\hline $\mathbf{3}$ & Age - Availability of food items other than prison food on extra payment & Negative, Rejected \\
\hline $\mathbf{4}$ & Age - Separate facility for the aged prisoners & Negative, Rejected \\
\hline $\mathbf{5}$ & Age - Good Feeling in the Prison & Negative, Rejected \\
\hline $\mathbf{6}$ & Age - Assigning hard Work & Negative, Rejected \\
\hline $\mathbf{7}$ & Age - Good behaviour by Prison Staff & Negative, Accepted \\
\hline $\mathbf{8}$ & Age - Facing problem/s in the Prison & Positive, Accepted \\
\hline $\mathbf{9}$ & Age - Availability of Good Quality Food & Positive, Accepted \\
\hline $\mathbf{1 0}$ & Age - Availability of Good Quality Water & Positive, Accepted \\
\hline $\mathbf{1 1}$ & Age - Availability of Good Quality Clothing and Other items & Positive, Rejected \\
\hline $\mathbf{1 2}$ & Age - Availability of Good Quality Mattresses & Negative, Rejected \\
\hline $\mathbf{1 3}$ & Age - Availability of Good Quality Utensils & Negative, Rejected \\
\hline $\mathbf{1 4}$ & Age - Availability of Good Quality Hygienic Facilities & Positive, Accepted \\
\hline $\mathbf{1 5}$ & Age - Availability of Good Quality Medical Facilities & Negative, Rejected \\
\hline $\mathbf{1 6}$ & Age - Availability of Good Quality Healthcare Facilities & Positive, Rejected \\
\hline $\mathbf{1 7}$ & Age - Availability of Good Quality Education/ Literacy & Negative, Accepted \\
\hline $\mathbf{1 8}$ & Age - Availability of Good Quality Library Facilities & Negative, Rejected \\
\hline $\mathbf{1 9}$ & Age - Availability of Good Quality Entertainment Facilities & Positive, Rejected \\
\hline $\mathbf{2 0}$ & Age - Availability of Good Quality Open Space within the Enclosure & Positive, Rejected \\
\hline $\mathbf{S u m m a r y ~} \boldsymbol{o f}$ results for Hypothesis $\boldsymbol{I}$ & \\
\hline
\end{tabular}

Hypothesis 2. Mechanism for safeguarding rights of the inmates enshrined in Legal provisions in India is inadequate to deal with the rights of inmates.

\begin{tabular}{|l|l|l|}
\hline SN & Proposed Relationship & Results \\
\hline $\mathbf{1}$ & Age - Sleeping Accommodation & Positive, Accepted \\
\hline $\mathbf{2}$ & Age - Ventilation facility in the Cell & Negative, Accepted \\
\hline
\end{tabular}

\footnotetext{
${ }^{11}$ IndraJeet Singh, "Indian Prison: A Sociological Enquiry”, Concept Publishing House, Delhi, (1979), p.1.

${ }^{12}$ Popularly known as The Nelson Mandela Rules

${ }^{13}$ The United Nations Standard Minimum Rules for the Treatment of Prisoners (the Nelson Mandela Rules), A/RES/70/175 (2015), hereinafter referred to as "the Nelson Mandela Rules", preliminary observation 1.
} 


\begin{tabular}{|l|l|l|}
\hline $\mathbf{3}$ & Age - Light facility in the Cell & Negative, Rejected \\
\hline $\mathbf{4}$ & Age - Outfits Provided & Negative, Accepted \\
\hline $\mathbf{5}$ & Age - Quality of Washing Materials & Positive, Accepted \\
\hline $\mathbf{6}$ & Age - Provision of Sports Activities & Negative, Rejected \\
\hline $\mathbf{7}$ & Age - Medical check-up by medical officer & Positive, Accepted \\
\hline $\mathbf{8}$ & Age - Information about their offence & Negative, Accepted \\
\hline $\mathbf{9}$ & Age - Understanding the right to speedy trial & Negative, Rejected \\
\hline $\mathbf{1 0}$ & Age - Understanding the right to complaint for any problems and irregularities & Positive, Rejected \\
\hline $\mathbf{1 1}$ & Age - Censorship Status & Positive, Rejected \\
\hline $\mathbf{1 2}$ & Age - Permission to make complaints in any visit of authorized officials & Negative, Accepted \\
\hline $\mathbf{1 3}$ & Age - Knowledge of Human Rights & Positive, Accepted \\
\hline $\mathbf{1 4}$ & Age - Imprisonment Information to family members & Negative, Accepted \\
\hline $\mathbf{1 5}$ & Age - Understanding of right to free legal aid & Negative, Rejected \\
\hline $\mathbf{1 6}$ & Age - Provision of Writing facility & Positive, Accepted \\
\hline $\mathbf{1 7}$ & Age - Permission to meet the lawyer & Positive, Accepted \\
\hline $\mathbf{1 8}$ & Age - Adverse effects of imprisonment & Positive, Accepted \\
\hline $\mathbf{1 9}$ & $\begin{array}{l}\text { Age - Provision of employment opportunities } \\
\text { in the prison }\end{array}$ & Negative, Accepted \\
\hline $\mathbf{2 0}$ & Age - Force for some illegal activities by the inmates & Positive, Rejected \\
\hline $\mathbf{2 1}$ & Age - Force for some illegal activities by the inmates & Positive, Rejected \\
\hline $\mathbf{2 2}$ & Age - Understanding of prison rules & Positive, Accepted \\
\hline Summary of results for Hypothesis II & \\
\hline
\end{tabular}

Hypothesis 3. Correctional programs implemented in Uttarakhand are not in consonance with Human Rights Jurisprudence

\begin{tabular}{|l|l|l|}
\hline SN & Proposed Relationship & Results \\
\hline $\mathbf{1}$ & Age - Relationship with other prisoner/s & Negative, Accepted \\
\hline $\mathbf{2}$ & Age - Solution of problems by prison staff & Negative, Rejected \\
\hline $\mathbf{3}$ & Age - Unsolved problems by Prison Staff & Negative, Rejected \\
\hline $\mathbf{4}$ & Age - Acceptance by family members after imprisonment & Negative, Accepted \\
\hline $\mathbf{5}$ & Age - Future Plans after imprisonment & Positive, Accepted \\
\hline $\mathbf{6}$ & Age - Educational Continuity after imprisonment & Negative, Accepted \\
\hline $\mathbf{7}$ & Age- After release & Positive, Accepted \\
\hline $\mathbf{8}$ & Education - Relationship with other prisoner/s & Negative, Accepted \\
\hline $\mathbf{9}$ & Education - Solution of problems by prison staff & Positive, Rejected \\
\hline $\mathbf{1 0}$ & Education - Unsolved problems by Prison Staff & Positive, Accepted \\
\hline $\mathbf{1 1}$ & Education- Proposed future plans & Negative, Accepted \\
\hline $\mathbf{1 2}$ & Education - Meditation classes in the prison & Negative, Accepted \\
\hline $\mathbf{1 3}$ & Education - Agricultural activities in the prison & Positive, Accepted \\
\hline Summary of results for Hypothesis III & \\
\hline
\end{tabular}

Prison Reform initiatives have a grim picture during the last two or more decades, most of the recommendations of Mullah Committee on prison reforms are yet to be implemented. It is an established fact that Centre and state government has made allocations for prison reform in areas like infrastructure development, providing legislative $\&$ judicial remedies. But building new prisons, introducing provisions like $436 \& 436 \mathrm{~A}$, the fast-track courts, LokAdalat is like curing symptoms not the disease. Therefore, it has become imperative that these initiatives needed to be assessed to set right our future strategies for prison reform initiatives.

Correctional machinery is an integral system and a principal organ of the criminal justice system. If the purpose of the system is to achieve prevention of crimes the system cannot afford to leave the correctional and rehabilitative aspect unattended.

The variables "Participation in the Cultural Programs which are conducted in the prison", "Availability of food items other than prison food on extra payment", "Separate facility for the aged prisoners", "Good Feeling in the 
Prison", "Assigning hard Work", "Good behaviour by Prison Staff”, "Availability of Good Quality Mattresses", "Availability of Good Quality Utensils", "Availability of Good Quality Medical Facilities", "Availability of Good Quality Education/ Literacy", and “Availability of Good Quality Library Facilities" are negatively correlated with age of prisoners residing in different jails of Uttarakhand. Whereas, the variables "Violation of rights in the Prison", "Facing problem/s in the Prison", "Availability of Good Quality Food", "Availability of Good Quality Water", “Availability of Good Quality Clothing and Other items”, "Availability of Good Quality Hygienic Facilities", "Availability of Good Quality Healthcare Facilities”, "Availability of Good Quality Entertainment Facilities", and "Availability of Good Quality Open Space within the Enclosure are positively correlated with age of prisoners residing in different jails of Uttarakhand. After due investigation along with the results of Chi Square test it has been identified that the traditional fulcrum of prison administration is too obsolete with the passage of time as the most of the factors, viz., "Good Quality Clothing and Other items", "Good Quality Mattresses", "Good Quality Utensils", "Good Quality Medical Facilities", "Good Quality Healthcare Facilities", "Good Quality Library Facilities", "Good Quality Entertainment Facilities", "Good Quality Open Space within the Enclosure", "Availability of food items other than prison food on extra payment", "Availability of food items other than prison food on extra payment", and "Facing problem/s in the Prison" were not ranked properly by prisoners. Hence, the null hypothesis is accepted.

The factors, viz., "Sleeping Accommodation", "Quality of Washing Materials", "Medical check-up by medical officer", "Understanding the right to complaint for any problems and irregularities", "Censorship Status", "Knowledge of Human Rights", "Provision of Writing facility", "Permission to meet the lawyer", "Adverse effects of imprisonment", "Force to perform illegal activities by the inmates", "Force to perform illegal activities by the inmates", and "Understanding of prison rules" are positively correlated with the age of the prisoners residing in the various jails of Uttarakhand. Whereas, the variables "Ventilation facility in the Cell", "Light facility in the Cell",

"Outfits Provided", "Provision of Sports Activities", "Information about their offence", "Understanding the right to speedy trial", "Permission to make complaints in any visit of authorized officials", "Imprisonment Information to family members", "Understanding of right to free legal aid", and "Provision of employment opportunities in the prison" are negatively correlated with the age of the prisoners residing in the various jails of Uttarakhand. After analyzing the factors associated to mechanism for safeguarding rights of the inmates enshrined in Legal provisions in India it has been identified that the said mechanism is adequate to deal with the rights of inmates as most of the factors, viz., "Sleeping Accommodation", "Ventilation facility in the Cell", "Outfits provided", "Quality of Washing Materials", "Medical check-up by medical officer", "Information about their offence", "Permission to make complaints in any visit of authorized officials", "Knowledge of Human Rights", "Imprisonment Information to family members", "Provision of Writing facility", "Permission to meet the lawyer", "Adverse effects of imprisonment", "Provision of employment opportunities in the prison", and "Understanding of prison rules" were ranked appropriate by prisoners. Hence, the null hypothesis is rejected.

The factors "Solution of problems by prison staff", and "Unsolved problems by Prison Staff" are positively correlated with the education of prisoners residing in the jails of Uttarakhand. Whereas, the variables "Relationship with other prisoner/s", "Acceptance by family members after imprisonment", "Future Plans" and "Educational Continuity after imprisonment" are negatively correlated with the education of prisoners. After due analysis regarding correctional programs implemented in Uttarakhand, it has been identified that these correctional programs are in consonance with Human Rights Jurisprudence as most of the factors, viz., "Relationship with other prisoner/s", "Solution to various problems by prison staff", "Acceptance by family members after imprisonment", "Future Plans after the imprisonment", and "Educational Continuity after imprisonment" were rated positively by prisoners. Hence, the null hypothesis is rejected.

\section{Conclusion}

Primary aim of imprisonment is to re-educate the offender for the purpose of realigning and reorganizing his life for smooth re-settlement in society. The treatment of offenders in prison should aim at instilling in them the will to lead law-abiding and self-supporting lives after themrelease. The treatment should foster their self-respect, self-discipline and sense of responsibility. To achieve this, the prisons should have properly trained personnel. The effectiveness of the institutional discipline and the impact of treatment mainly depend on the quality of the correctional staff.

The prison administration shall provide for careful selection of prison personnel, since it is on their integrity, dedication, humanity, potency, and personal suitability for the work that the proper administration of the institution depends. They should be paid adequate salary and they should have a civil service status with security of tenure The Inspector- General prisons should have similar fixed term of office and the present practice of appointing senior police officers as InspectorGeneral Prisons should be dispensed with. On joining their duty, the prison officials should be given adequate training in correctional administration. Their general service conditions should be improved so that the prison service can attract best talent. The prison personnel shall be properly 
selected and adequately trained in various aspects, of intuitional management, as well as in theories of correctional work. The welfare of the personnel shall be adequately attended to.

\section{References:}

1. David Arnold, Colonizing The Body: State Medicine And Epidemic Disease In Nineteenth Century India 113 (1993).

2. Dr. L.P Raju, Historical Evolution of Prison System in India, 4 INDIAN JOURNALS OF APPLIED RESEARCH

3. Gresham Sykes, "The Pains of Imprisonment" in Norman Johnston, Leonard Savitzet al. (edi.), The Sociologyof Punishment and Correction, John Wiley\& Sons, Inc., New York, (1962)

4. AL ZOUBI, H. U. D. A. "THE ROLE OF SOCIAL SYSTEM IN THE ADMINISTRATIVE DETENTION FOR JORDANIAN WOMEN (A FIELD STUDY ON WOMEN UNDER ADMINISTRATIVE DETENTION IN JORDANIAN PRISONS)." International Journal of Environment, Ecology, Family and Urban Studies (IJEEFUS) 10.1, Feb 2020, 1-12

5. Harald Fischer-Tine, Empires and Boundaries: Race, Class and Gender In Colonial Settings 52 (2008).

6. India and the Colonies, 1 The British Medical Journal 784 (1884).

7. J. ChinnaDurai, Indian Prisons, 11 Journal of Comparative Legislation and International Law 245, 248 (1929).

8. RUB, ARBAB MOHAMMED ABDUL. "CARLTONA DOCTRINE IN ADMINISTRATIVE LAW." International Journal of Political Science, Law and International Relations (IJPSLIR) 7.6, Dec 2017, 1-8

9. James H. Mills \&SatadruSen, Confronting the Body: The Politics Of Physicality In Colonial And PostColonial India 102 (2004).

10. Manual- Lopez Rey, The First UN Congress on Prevention of Crime and Treatment of Offenders, Volume 47, Criminal Law, Criminology \& Police Sci. 526 (1956-57),

11. Nandini Bhattacharya, Contagion and Enclaves: Tropical Medicine in Colonial India 17 (2012).

12. PANDYA, DIGVIJAY, and AARTI MAHAJAN. "JEAN SASSON: AN EXISTENTIAL PERSPECTIVE OF MIDDLE EAST." International Journal of English and Literature (IJEL) 8 (2018): 63-68.

13. Negley K. Teeters: "The cradles of the penitentiary (Pennsylvania) prison society,"

14. Nitin Sinha, Communication and Colonialism in Eastern India: Bihar, 1760s- 1880, 182 (2014).

15. PremChowdhry, Colonial India and the Making of Empire Cinema: Image, Ideology and Identity 162 (2000).

16. Akram, M., et al. "Causes and Implication of Male Youth Violence/Crime in the Punjab, Pakistan." International Journal of Educational Science and Research 3.1 (2013): 113-122.

17. Rupert Cross, Punishment Prison and The Public, Stevens and Sons, London, (1971)

18. SatadruSen, A Separate Punishment: Juvenile Offenders in Colonial India, 63 The Journal of Asian Studies

19. The English Prison and BorstalsSystem (1952)

20. Justice Krishna Iyer, Human Rights \& Inhuman Wrongs, B.R. Publishing Corporation, Delhi (1990)

21. Krisha Murthy, S., Human Rights \& the Indian Police, R.R. Publishers Bangalore (1 st Edition 1994)

22. Ahmad Siddique's: Criminology \& Penology (2011)

23. AmarendraMohanty, Indian Prison System, Ashish Publishing House, New Delhi, (1990)

24. Chandha, Kumkum: Indian jail: A contemporary document. (VikasPublisher, New Delhi, 1983) (ILI)

25. Chakraborty, $\mathrm{n}$ k ed.: Institutional correction: In the administration of criminal justice. (Deep \& Deep Publisher, New Delhi, 1999) (DELNET)

26. Chowdhury, Nita R: Indian prison laws and correction of Prisoners. (DELNET)

27. Corrections and conditional release act. (Canada, 1996) (NHRC)

28. David Sky, Macaulay and the Indian Penal Code of 1862, 32 MODERN ASIAN STUDIES 513, 526530 (1998).

29. Dirk Van ZylSmit, "International Imprisonment", The International and Comparative Law Quarterly 2005 Cambridge University Press

30. SHALI, SONIA. "UNRESTRAINED MEDIA AND JUVENILE DELINQUENCY: AN INTERDISCIPLINARY EXPLORATION." International Journal of Humanities and Social Sciences (IJHSS)(6.4) (2017): 81-98.

31. Donald R. Cressy, "The Prison: Studies in Institutional and Organizational and Change", Holt, Rinehart and Winston, Inc. New York

32. George Ruche and $\mathrm{O}$

33. Tot Kirchheimer, punishment and social structure (Columbia university press, New York 1939).

34. Ghosh, S.: Open prisons and the inmates: A socio-psychological study(Mittal Publications, New Delhi, 1992) (DELNET)

35. Gonsalves, Colin, Sakhrani, Monica \&Fernandez, Annie: Prisoner's rights. (VaniPrakashan, Bombay, 1996) (NHRC) 
36. Elasri, Khalid. "A linguistic and cultural analysis of sympathy, compassion, empathy and pity in English and Moroccan Arabic." International Journal of Linguistics and Literature 7.4 (2018): 81-90.

37. IndraJeet Singh, "Indian Prison: A Sociological Enquiry”, Concept Publishing House, Delhi, (1979)

38. Leon Radzinowicz, A history of English Criminal Law \& its Administration from 1750,Vol.1

39. M.J. Sethna, Society and the Criminal, N.M. Tripathi Pvt. Ltd., Bombay, $\left(3^{\text {rd }}\right.$ edi., 1971)

40. Paul F. Cromwell, Jr., Jails and Justice, Charles Thomas Publisher, Springfield (1975)

41. Prof. N.V. Paranjape: Criminology, Penology \&Victimology,(2017)

42. Prof. N.V. Paranjape: Criminology, Penology \&Victimology,(2017)

43. Sharma P.D: Police and criminal Justice Administration in India, (1985)

44. VidyaBhushan, Prison Administration in India, S. Chand \& Co., (1970),

45. Vold G. B; Theoretical Criminology (1958 Ed.) 